\title{
5 ETUDES ON BODY WITHOUT ORGANS
}

\section{Ivan N. Belonogov}

${ }^{a}$ Institute of Philosophy, Russian Academy of Sciences. 2/1 Goncharnaya Str., Moscow, 109240, Russian Federation. Email: ligneofflyight[at]gmail.com

\begin{abstract}
The concept of "Body without Organs (BwO)" proposed by Gilles Deleuze (and Félix Guattari) is quite often overlooked both in the "post-Deleuzian" literature and in various systems/media theories. This paper aims to show the changes that might occur when introducing this concept in different discourses. Specifically, in terms of the systems theory, BwO resolves the paradox of "a certain system in the state of uncertainty" as well as opens the way to the neorationality; in the philosophy of life, it makes the zone of indistinguishability between life and death clearly visible; against the background of the identity politics, it becomes the guiding idea of liberation; while in the context of the media theory, it unfolds the mode of existence of the worlds of fantasy. The outcomes of this study may be useful not only for philosophers addressing the issues of systems, organizations, technics, media etc., or for political activists, but also for anyone interested in the philosophical heritage of Gilles Deleuze as well as in the development of his philosophical ideas.
\end{abstract}

\section{Keywords}

Gilles Deleuze; Body without Organs; organization; system; life; disorganized; liberation; Whole; resonance; media 


\section{5 ЭТЮДОВ НА ТЕЛЕ БЕЗ ОРГАНОВ}

\section{Белоногов Иван Николаевич ${ }^{\mathrm{a}}$}

a ФГБУН Институт философии Российской академии наук. 109240, г. Москва, ул. Гончарная, д. 12, стр. 1. Email: ligneofflyight[at]gmail.com

\section{Аннотация}

Концепт «Тела без Органов» (ТбО) Жиля Делёза (и Феликса Гваттари) нередко обходится вниманием, как в постделёзианской литературе, так и теориях систем и теориях медиа. В данной работе ставится цель показать, что изменяется при введении этого концепта в различные дискурсы. В теории систем ТбО решает парадокс «определённой системы в состоянии неопределённости» и открывает путь для нео-рациональности; в философии жизни оно делает видимой зону неразличимости жизни и смерти; в вопросе политики идентичностей оно становится путеводной нитью освобождения; в контексте теории медиа - раскрывает способ существования фантастических миров. Выводы данной работы могут быть полезны как философам, занимающимся вопросами систем, организаций, техники и медиа, так и политическим активистам, а также всем интересующимся философским наследием Жиля Делёза и развитием его философских идей.

\section{Ключевые слова}

Жиль Делёз: Тело без Органов; организация; система; жизнь; дезорганизованное; освобождение; целое; резонанс; медиа

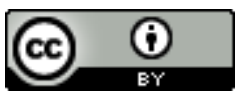

Это произведение доступно по лицензии Creative Commons «Attribution» («Атрибуция») 4.0 Всемирная. 
0

This paper is not intended to give an interpretation of the concept of Body without Organs. It does not explore what Body without Organs is. It is not some sort of an interpretative note, whilst being able to be used in this way. It is composed of five cartographic essays about where and how Body without Organs can function in multiple vastly different environments.

These environments might as well be labelled as "academic" and "political", as if these labels could reflect the subject matter, i.e. as if it would be possible to make a distinction between "academic" and "political" environments without any misrepresentation. However, it is important to point out that these designations are introduced exclusively for reader's convenience, i.e. to provide some familiar orienting points.

The first essay addresses the self-organizing/self-developing systems theory paradox that can be resolved in terms of the concept of Body without Organs.

The second one explores the boundary delimitation issue that falls within the cognizance of the discipline. Therefore, we note beforehand that the line separating these two essays is quite blurred.

In the third essay, the issue of life and death is addressed, in terms of which Body without Organs is considered as the zone of their indistinguishability.

It is the aforesaid three essays that can be identified as "academic", since they explain why the decent people, academicians, would need Body without Organs.

The fourth essay is written in terms of freedom, and it will assert that "freedom" is always already granted, while the lines of flight must be drawn anew each time.

The last, fifth, essay addresses Body without Organs within the context of the media space where media can be viewed as a launching ground for the creative potential.

That being said, any text represents a statement. Therefore, it comprises inherently something "political".

Five essays, five angles of viewing the problematic areas, as well as five way-outs that can be opened through usage of the concept of Body without Organs. 
The systems theory is primarily a theory of open systems.

Any closed system follows the laws of thermodynamics, meaning that its entropy grows with time. It moves from order to chaos, and thus the order and the chaos are its starting and ending points, respectively. Within the frameworks of this model, the order and the chaos do not exist simultaneously, although they represent a continuum coinciding with the timeline.

The "open system", i.e. a system that exchanges energy with the environment, while including this environment as part of its own organization, establishes a completely different relationship between the chaos and the order. Both of them take on a relative nature, where the order is the internal order of the system, while the chaos, from the point of view of this system, not only represents its surroundings, but also gets inside, infiltrating into its well-structured components and mechanisms. In terms of this model, the order and the chaos do exist simultaneously, and the disorder can be viewed as an environment organized and ordered by the system through its very functioning. On the other hand, the time becomes reversible, when measured based on the phases and phase transitions the open system undergoes. Depending on the choice of system, it can either progress to a higher level of order or regress to an earlier state:

«The order out of disorder that emerges in an open system's interaction with its environment is subject to fluctuation. When certain levels of fluctuation are created by increasing complexity, a critical or bifurcation point is reached. At that point the system can move in any one of several directions until a new and more complex order may be established after a period of turbulence. If a higher order of organization does not emerge, the system returns to a previous, lower level of organization» (Morin, 2007, p. 35).

For the chaos, its phases of order alternate with its transition phases. And while the system, when in the phase of order, or homeostasis, or metastability, defines its own territory, takes on a certain form, sets and delineates its own borders, 
determining what belongs to its internal organization and what represents its exterior, in the phase of chaos, the system is deterritorialized, becoming "naked and defenseless to any, however small, external influences" (Budanov, 2017, p. 37). The way how this transition moment is described can be seen as a paradox, since when we state that a certain system undergoes the phase of formation where it loses its certainty, we have to accept two contradictory points, namely: (1) the system has passed into the mode of formation and became uncertain and (2) we speak about the same system as a certain one (the one undergoing this very phase). Here the question may arise: how can we say that we speak about the same old system, when there is no any system at the time we speak? How can we determine a system when it changes and loses its shape, merging with the surrounding chaos?

This paradox arises from the fact that the integrity of a system depends on its orderliness. Triad "Order $\leftrightarrow$ Organization $\leftrightarrow$ Disorder" introduced by Edgar Morin indicates clear preponderance of the organization. That being said, Morin points to a "concealed, hidden and obscure zone abound with suppressed potentials", resulting from the fact that the "organizational constraints immerse in a world of silence the characteristics that are inhibited, repressed, and compressed at the level of the parts" (Morin, 2007, p. 102). When we focus on the organization and associate the "organization" to the "whole", even though we add that the "totality is always distorted and incomplete" (p. 103), we will always overlook the potential of the parts. Indeed, any given organization may ignore them, hiding or holding them back. However, for one thing, containment of forces is a question of a threshold that may be exceeded (when the potential of a part is so great that it breaks the system limitations); for the other, the organization may change, thus providing access for the whole to the features that were previously forbidden or hidden. When a formation persists for longer than one phase of organization, all the potentials of the parts must also be attributed to it, since the whole thrives on the parts one way or another. Therefore, according to Thanem, the organization theory should be supplemented with a nonexcludable amendment in the form of Body without Organs, i.e. a non-organized component of any formation (Thanem, 
2004). As a result, it becomes possible to include all the potentials hidden by the organization into the concept of "the whole", i.e. Body without Organs.

To do this, the first step is to introduce Body without Organs as a pole opposite to the organization one and related to the latter with the "reciprocal presupposition" relationship (Castro, 2014, p. 114-121). Here either pole represents a certain angle of view of the other one as well as the processes occurring between these two. Therefore, we can speak about two points of view:

Let us call the optics, only allowing us to see the extensive mechanisms with a greater or lesser degree of certainty and taking the order and organization as a reference point, "the point of view of the strata", while its adherents - "Agents of the Order". In this case, the reference point will be the extensive pole, for which the actual aspect will be the primary substance, while the virtual aspect will represent the effect of actual occurrences. This is the point of view of an observer immersed into the actuality (always featuring multiplicity and divisibility), gliding over the surface of stratification. To this observer, only the fact that "behind each stratum, encasted in it, there is always another stratum" (Deleuze, 1987, p. 159) can be clear.

Another optics takes the intensive pole, from which the virtuality turns out to be the primary substance, as a reference point, while for the actuality we assume that "the present itself is only the most contracted level of the past" (Deleuze, 1988, p. 74 [author's italics]). Here we begin with the Whole, the ontology of the world described by Deleuze as follows:

«A gigantic memory, a universal cone in which everything coexists with itself, except for the differences of level <...> All these levels or degrees and all these points are themselves virtual. They belong to a single Time; they coexist in a Unity; they are enclosed in Simplicity; they form the potential parts of a Whole that is itself virtual» (p. 100).

Let us call this point of view "the point of view of the consistency plane" or "the point of view of Body without Organs", because it is this point of view that we take when becoming Body without Organs. 
The second step is to make transition, i.e. switch over to the point of view of the consistency plane in order to see what role Body without Organs plays and then come back, introducing it as another dimension.

From the point of view of the strata, it is the machines that do all the work, while Body without Organs is just there. Various actions, assemblages and organizations occur, and at another (higher) level they are represented as single objects that are also included in the assemblages (DeLanda, 2006). Here the whole does not play a special role as a separate entity. However, in terms of Body without Organs, it is Body without Organs that originates all actions, while not constituting them: "It falls back on all production, constituting a surface over which the forces and agents of production are distributed, thereby appropriating for itself all surplus production and arrogating to itself both the whole and the parts of the process, which now seem to emanate from it as a quasi cause" (Deleuze, 1983, p. 10). In terms of $\mathrm{BwO}$, Body without Organs is the only cause of all these interactions, and it is Body without Organs that triggers the entire process, making the machines to act in concert. "Even if we consider given social formations, or a given stratic apparatus within a formation, we must say that every one of them has a $\mathrm{BwO}$ ready to gnaw, proliferate, cover, and invade the entire social field, entering into relations of violence and rivalry as well as alliance and complicity" (Deleuze, 1987, p. 163).

Within the strata framework, we will only find mechanisms that fade away at the moment the system enters the phase of formation. However, in terms of the consistency plane, the entity the system constituted before it took on some organization, i.e. before it became a system, was Body without Organs. It is not deducible insofar as, from the point of view of the strata, it does not produce anything: it simply exists (similarly, the Actor-Network theory remains as well within the strata framework, since it takes notice of nothing but what produces an action). It is based on Body without Organs that the organization arises, and it is based on the same that it collapses. Therefore, introduction of the "whole" as another dimension means that it is Body without Organs, rather than the system or the assemblage, that undergoes the phases of homeostasis and formation, 
providing a basis for stratification and territorialization, as well as deterritorialization and destabilization.

Body without Organs is opposed to an organism, or an organization, as a pole limit that can be approached, while not being worth to be reached, and as a viewpoint whose center of gravity is shifted towards the consistency plane. At the same time, it represents a concept that can be considered in more detail using these transitions between various viewpoints in order to find a perspective from which both the organization and Body without Organs can be seen as equal participants. Indeed, there are some organizations; even better, sometimes they are even devoid of any faults or contradictions. However, this does not exclude the fact that the whole exists as an additional dimension that is independent of any organization's inconsistency and persists even if there is no organization. Body without Organs is disorganized and uncertain. And it is Body without Organs that allows us to escape the paradox of "uncertainty of a certain system": when external fluctuations undermine the established order, the borders are broken, the exterior merges with the interior, and the identity dissolves, leaving alone Body without Organs - the integrity of chaos featuring action limits.

\section{Interlude}

Of course, we might do without introducing the concept of Body without Organs to point out the integrity that persists even where nothing is certain, since the same function can be assumed by the Name. We might just say "yes, in the phase of formation, the system ceases to be a system, but its name remains and can be inherited by what will develop in its place" (and then we can say "here is the same system that has come to a new homeostasis"). However, for one thing, this would cause unnecessary disputes about the right of inheritance and genealogy ("should we call the new entity with the same name when it has changed beyond recognition?"). For the other, in this case, we would have to forbid this entity to change its name, as well as to require that it is always called using the same name, whatever transformations have happened to it. This would mean coming back to the name dictate, which is likely to be good enough for Agents of Order (because they are so fond of 
dictation). In order to calm them down, it is worth reminding another benefit of Body without Organs (after all, benefit is the main euphoriant drug for Agents of Order) as related to the question of borders and limits.

2

In its "Lectures on Spinoza", Gilles Deleuze highlights, among others, two concepts of limit, namely, the Greek and the Stoic ones.

The Greek concept of limit refers to the limit contour. "A certain volume has a surface as a limit" (Deleuze, 2016, p. 135). Some object has a certain volume, and this volume has a surface that outlines its contour and serves as its shape. In terms if this concept, the matter of the object becomes irrelevant, as it will always have a shape that will remain the same, whatever it is made of, whether it pertains to a pure spirit or a matter of thought. As long as the shape persists, the object will remain the same.

Although this concept was found by Deleuze back in Plato, it is also used in the systems theories that adhere to organicism ("organization remains identical to itself even though all of its constituent parts have been renewed" (Morin, 2007, p. 17)). Here, the form is equivalent to the entity, and the latter, in its turn, is tied to the following conception: "the optical form is correlated even by sight - with the tactile contour" (Deleuze, 2016, p. 136). However, this tactility, i.e. "capturing the form", still remains subordinate to the visibility: the surface can be encountered, its contour can be sensed tactilely, and with further examination by touch the contour will take a form, and this is the only way of becoming aware of the essence of things (to comprehend, you still need to see, even with the use of your hands). This is why Deleuze claims that this is all about an analogy between the eye and the hand, as both of them are dedicated to the same goal, namely, outline of the form. This is why Plato's "eidos is a term that refers to visuality, i.e. something visible, namely, speculation" (p. 136).

A completely different concept of limit, namely, the action contour, was found by Deleuze in the Stoics ${ }^{12}$. Not everything in

\footnotetext{
${ }^{12}$ As Deleuze notes, "the Stoics are not the Greeks; they are on the periphery of the Greek world" (Deleuze. 2016. 138)
} 
the world has a form. The form is nothing but a surficial consequence of the forces acting deep. This is why the Stoic concept is deeper than the Greek one. "The limit of a thing is the limit of its action, rather than the contour of its shape" (p. 140). As an example, Deleuze cites the sunflower seed, the forest and the light. Description of the shape of a sunflower seed will tell us nothing about what it is.

"The forest [in its turn] is not defined through its form; it is defined through its potency, namely, the potency of letting trees grow until it is no longer able to do so. The only question to the forest I have to ask is "what is your potency?" I mean, "how far will you get?" This is what the stoics discover and what allows them to say: everything is a body" (p. 140).

This is also true for the light, as it extends as far as its potency will allow; however, its limit is not outlined with a contour (unless some other force stops it and then, as a result of this collision, a clear border appears on the surface).

This will be true for any Body without Organs - it has an action limit. Either the chaos or the order spread, going constantly beyond its contour borders. Moreover, they can spread not only within the physical space (photo, video, text, sound etc.), as many various entities may as well act through them via infection. For example, spread of the panic is effected in such a way. And while it is impossible to outline its form, it is possible to determine the limit of its action. It will capture more and more carriers until some other force either strikes it back, or blocks it, or reduces it to nothing (for example, by absorbing it). Individuals, states or societies - all of them outline the contours through forced propagation, while acting at the action limit and leveraging the opposition of other entities, and it would be a mistake to take these contours for the actual borders.

Seeing nothing but the established borders, or contours, we find ourselves in the space of something conceivable, limited by the classical rationality, i.e. something that is conceivable only when it is representable and expressible. The classical concept of rationality treats a thought as something that deals with a certain image. It is always a thought about something, a thought representing something. In terms of this rationality, we will 
always be at least three paces late, as we will formulate a statement about something not until it has taken a shape and become representable.

There is also another type of thought found by Deleuze in Spinoza, namely, the unrepresentative affect thought (Deleuze, 2016, pp. 10-11). From this point of view, to feel, perceive and act is to think, but think without an image. The model of rationality limited to something imaginable is opposed with the practice of mental action. Essentially, this refers to the non-philosophical thought-world (lauriel). Based on this neo-rationality, we can both think and act in real time, seeing what is happening, and not just what is being said. There are no more hidden details; on the contrary, there is a unified space of life and forces, i.e. Body without Organs that makes us think differently.

Both the chaos and the order are always the chaos and the order of something within which they arise. Therefore, BwO has a limit, but not any contours of the form. Being neither a thing nor a force, it is still there, while not being [something certain], a "luminous mist", a piece of something rather than nothing. And only through thinking about it, or even becoming it, we are able to observe the battle of anonymous forces that takes place permanently at a depth of the things. In contrast, if we stay true to the strata, we will always take force effects for the forces themselves, always dealing with something generated by the life, something that happens in the life, and never with the life itself.

\section{3}

Ben Woodard shows a surprising line of thinking in his "Slime Dynamics" (Woodard, 2016). Starting from criticizing Deleuze (along with Bergson), he tells us about Body without Organs throughout the course of narration; then, while predicting the arrival of the radical Outside, he does not notice that Body without Organs is eminently "like the absolute Outside" (Deleuze, 1987, p. 156); finally, as the strangest paradox, following Eugene Tucker, he promises moving away from anthropocentrism, tying firmly to the "Horror", a purely human affect, the very retreat in the face of something non-human, 
which is the key barrier obstructing entering into the inhumanism ${ }^{13}$.

At the same time, the "Slime Dynamics" shows Body without Organs to be not only the Death (as Deleuze often reminds us), but also the Life. Specifically, a slime mould is a living creature staying, along with the viruses, closest to the consistency plane, providing the most illustrative example of Body without Organs among the well-known organisms recognized as living creatures. It has no predetermined or permanent organs or a form and, while being integral, can be divided without any serious harm to it. After all, would this not give an indication that a living creature continues to live even when injured, where the strata integrity is compromised, providing the best evidence that neither strata nor organizations (that are always self-contradictory, as Gödel showed), nor logical machines, can be considered as living, but only a kind of open unity, for which the visible form is nothing but the result of the struggle of forces.

However, if the life (and, of course, the death) is not a concept, but rather a practice, as is the case with Body without Organs, how can we approach them? Here we can determine two ways to conceptualize the life: the first one is to explore the surrounding life, the life of others - trees, microbes, people, slime moulds etc.; in other words, the others' life; while the other one runs through one's own experience, understanding of the life as a practice, with which all of us are consumed as long as we are there. Following the second path, Deleuze gives the following example in his "Lectures on Leibniz":

"When my consciousness relaxes, I am captured with small perceptions that still do not become conscious; they do not become apperceptions, because they capture my consciousness only when it is disorganized. It is at this moment that I am filled with a sea of small perceptions. The issue is not that these small perceptions cease to be conscious, it is that I cease to be cognisant. However, I do experience them, I have experienced them unconsciously. I

\footnotetext{
${ }^{13}$ See, for example, "Revolution of Slime" by Anton Zankovsky (in "Aristotle and Shore Whores" or in Logos Journal) where the linkage between Horror and anthropocentrism is revealed.
} 
don 't represent them, I don't perceive them, but they are there, they are abundant" (Deleuze, 2015, p. 78).

For the classical representative rationality, the states like these are called "gloomy" and are rejected as unthinkable, since they exclude the possibility of reflection and representation, the possibility of being aware of the moment when we slip into these states. At the same time, in the course of our life, we experience them, undergo them without ceasing our [living] activity. "We don't even need to pursue this thought experience, we know it's like that, so through thought, we look for the kind of experience that corresponds to the principle of fainting" (p. 78). But the states like these are not yet the limiting case; however, they do open the way for us to imagine the limiting state, the extreme degree of disorganization, liquefaction, when there is no mechanism left for putting everything back together and start it up - the principle of fainting, the death instinct, Body without Organs. "Leibniz goes much further and says: wouldn't that be death?".

Indeed, Body without Organs is often referred to as "death instinct". Therefore, we should make a small excursion into the history of this concept. It was introduced by Freud in his "Beyond the Pleasure Principle" as an opposition to the life instinct. Its name is Thanatos. Back at that time, he noticed that the death instinct itself is not given to us in its pure form, but always mixed with the life instinct. After all, the will to live - Eros or the pleasure principle - is all that is given to us. The pleasure principle is not subject to exceptions, governing our experience. How does it work? First, the pleasure principle overmasters any repetition. Each moment of our life is different from another one; however, in this 'ocean of difference', there are always some replications. Originally, these replications just happen, for some metaphysical reason. Some of them bring pleasure, while the other - unpleasant sensations. The pleasure principle stimulates an individual to reproduce the situations that caused the pleasure. So the repetition subordinates to the pleasure principle. Second, the life instinct is a binding instinct. It binds the sequences leading to pleasure together into algorithms, and then binds these algorithms together to secure them as higher-level structures. Thus in the world of an individual, 
something is formed referred to as "the comfort zone" by the psychologists and "the homeostasis" - by the systems theorists. As Ayten Juran notes, "both the pleasure principle as a tendency towards decrease in the amount of energy in the mental apparatus and the reality principle appearing to be the same pleasure principle, however, on the deferred paths with the same tendency, function within the logic of homeostasis " (Ayten Juran, 2018). Thus the pleasure principle represents the logic of homeostasis and stability, by which the random nature of repetitions is tamed, obeying the order of algorithm systems. The life instincts are characterized by inertia, conservatism, drive for return to previous states and maintenance of the established organization. They stratify. They establish the Law. "The stabilizing force prescribes the homogeneous and integral nature to our reality as it exists, fixing a priori the limits of what is possible" (Regev, 2016, 62).

We would certainly be confined within these limits, violated only by occasional external stimuli, were the life instincts our only instincts. However, even though the pleasure principle is not subject to exceptions, there is something beneath it that interferes with the established order. While the life instinct is what is given to us, the death instinct should be sought beyond the givenness, beyond what turns out to be possible for us. Therefore, Deleuze suggests categorization into the death instincts that always appear as pre-mixed with the life ones, as a shutdown of algorithmized processes, as irregularities and failures, and the pure death instinct, the transcendental principle, about which we only can speculate (Deleuze, 1991, p. 30). There are at least two ways of these speculations that, following Yol Regev, can be designated as sadistic and masochistic [methods] ${ }^{14}$. "The first represents a speculative and analytical manner of apprehending the Death Instinct - which, as we have seen, can never be given - while the second pursues the same object in a totally different way, mythically, dialectically and in the imaginary" (Deleuze, 1991, p. 35).

The sadist, as it appears in the books of Marquis de Sade, is the pure Super-Ego, Reason and Law personified in libertin. Its

\footnotetext{
14 Besides the Deleuzian "The Representation of Sacher-Masoch", analysis and conceptualization of these two methods can be found in Regev's "The Impossible and Coincidence. On the Revolutionary Situation in Philosophy", pp. 60-73.
} 
motto is "the order is necessary in everything, even in the rage of lust and malice" (de Sade, 2011, p. 79). A clear daily routine, nutrition, systematic arguments that lead to violence against others and, ultimately, against oneself. The sadist is a carrier of the pure universal law. That being said, the decisive factors are hidden tendencies, guiding forces rather than evident consequences. And where the sadist goes, as well as where he applies the power of reason, is the pure primary chaos. To achieve this, the sadist uses the method of double transgression (double crime). The first step is to break the law and end up in chaos. However, this is not enough, because such chaos is just the reverse side of the law, just a different order. Behind this limited chaos, the sadist recognizes another chaos that is no longer associated with the 'order-disorder' binary opposition. However, such chaos can never be given; it can only be conceived by the sadist as a result of double negation - negation of order and negation of the 'order-disorder' binary opposition. Thus, through apophatic thinking, the sadist discovers the death instinct in its purest form, namely, as Great Negation of everything. The death instinct is conceptualized negatively and meaninglessly.

The road of masochist, as drawn by Sacher-Masoch, goes through double suspension. The masochist is the Freudian Self playing with the Law with a humorous undertone. At the beginning, the masochist rejects the Law that, for the imperialist mindset, is associated with the figure of Father and therefore appears as Phallus, thus transferring it to a woman. The masochist concludes a contract with a woman, according to which she gets complete power over him. Thus the masochist is suspended between two mutually exclusive affirmations acting in equal measure: on the one hand, Mother Woman does not possess Law or Phallus, on the other, she does. This is the masochist's humor built on the flight of imagination: persuade a woman to sign a contract and then establish the Law that will now belong to her. This is the mythological element of masochism. This is how the masochist 's Super-Ego is brought into outside to be transferred to the woman, allowing him to become the pure Self free of any self-control. At the next step, the woman will punish the masochist, although he has not yet committed anything. The second joke of the masochist is that 
the law prescribing punishment for an offence is played out on its own field: the punishment that is executed before any offence has been committed becomes a requirement to commit the offense. What is punished in the masochist is his father-likeliness. The masochistic act removes the last remnants of Super-Ego from the body of the masochist, thus promising him an access to the forbidden pleasure. Of course, as soon as the punishment stops, the masochist will find himself again in the world of social order. However, as long as the punishment lasts, the masochist is in suspension: the contract is based on nothing, while producing a law, and this Law, in its turn, breaks free of the contract as its origin, becoming the Law of the Mother who, through punishment of the masochist, promises him rebirth, i.e. becoming an ideal Self born of the woman alone. Therefore, while the sadist's movement represents an ever-accelerating movement of crimes through which he tries to keep up with the pure negation, the masochist's movement, in contrast, involves suspension and hanging in the process itself. Al that's happening creates its own reasons. Mutually exclusive affirmations ("Law-Phallus belongs to Father" / "Law-Phallus belongs to Mother", "I was born from a sexual relationship between a man and a woman" / "the [ideal] Self was [re]born from a ritual performed by a woman alone") resonate with each other, erasing the previous order and origin ("through a contract with a woman, I established a Law that now belongs entirely to her"). The resonance itself appears to be both the consequence and the foundation. Through this ritual mythological practice of forgetting the origin and the Law, the death instinct comes up in its positivity, appearing no longer as a conceivable denial of everything, but rather as a foundation for itself, as an impossible (in terms of common sense) possibility. And now, having made our way along the masochist road, we can say for the death instinct: "And yet we must speak of it for it is a determinable principle, the foundation and even more of psychic life" (Deleuze, 1991, p. 30).

This is not so much about perversions (although they play their role, teaching us that it is only by going beyond the boundaries of the pleasure principle, refocusing the desire so that "the real becomes the priority" (Merzlyakov, 2019, p. 257), rejecting the Law and Common Sense, accepting the pain and 
the death as a constituent part of our life, that we can discover the Outside), but rather about two ways towards Body without Organs: the sadistic way of thinking, the Reason that is accelerated to the point that it breaks its own limits, moving towards the chaos, whereupon transgresses as well the latter so as to think of the Hyper-chaos just as the super-negation, the death; and also about the masochistic way of imagination, the dialectical way of suspension within insoluble contradictions so as to feel their resonance as a self-foundation, the Life - a foundationless foundation. In examining the life of others, we can only define it as a process, as an organization. This is true, for the life manifests itself in the activity. But it is nothing but the consequences of the life that we deal with, nothing but one side of life's face. There must be something else behind all this. Animals in anabiosis, viruses outside of their carriers - all they do not act, do not breathe, do not pulse, but do remain alive.

In such a way, the other side of life is revealed, namely, the foundation of the life as a force that exists but remains inactive. One, short (virtual) moment before a living being begins its activity, it is already there, already alive, although inactively. First of all, the life is the passiveness, the perception, and only secondarily it is an action. It is the existence of the open whole. The opposite is also true: "The death is the state of a living being that does not cease to live" (Deleuze, 2015, p. 79). After all, if there is no one who dies, then there is no death. And Body without Organs is the whole preceding any organization, the foundationless foundation, the point of indistinguishability between Life and Death. The body of potentiality. The living body.

4

The discourse of liberation is the discourse of slaves.

Rely on the strata and you will always be late. After all, the strata are something that has already happened, established themselves and managed to become freezed. The order is tied to its own genealogy, representing rhythmic repetitions of what has happened. That why the order is tied to its own past. The same is true for the identification: saying "I", we mean our past states and actions. When we say "I am this or that", we impose restrictions on ourselves and make the promise: "I am what I am", meaning "I 
promise to be the same as I used to be". Therefore, any first-person speech is always an indirect speech. This is a speech on behalf of someone else, whom we call "I", who we were, and for whom we are now speaking.

At best, we become slaves to ourselves, while flattering ourselves that we are also our own usurpers.

It is not always our pleasure principle that establishes the order, linking various events and organizing their repetition. More often, this order has already been established by someone else. Since our very birth, we are surrounded with the established order (the laws of language, grammar, behavior etc.) that entwists our bodies and then gets inside to dictate from there under the guise of "internal monologue". Our parents are the first to stake out a claim for us, whereupon they transfer their rights to the state, so that the latter, in its turn, can offer them to us as a gift - of course, a binding one. After all, our property, and each of us as a "person", as one's own property, are possible only subject to availability of the socio-economic order that determines the meaning of "property" and "personality", their boundaries, possibilities and application.

Big Brother is not alone, even if he tries to appear so.

There is the opposition, there is the left-wing idea, and there are mavericks. However, what was a way out yesterday may turn out to be a trap today. How long has it been since some author came up with some concept, described it and then published it? While moving "in tune with the times", we remain in place. Therefore, it is necessary to run twice as fast. It's all about the speed. After all, in addition to being late in finding the way out, or being freezed in the strata, our perception is inherent in the memory. The actual is the past. Differentiation always involves delay. Being actual means being late for a moment. This is not enough.

Before we can accelerate the capitalism, we need to accelerate ourselves.

The destratification itself is not enough. Having spent a long time looking for a way of going beyond the language constrains by effort of the language itself, William Burroughs eventually came to conclusion that this was impossible (Land, 2005). While passing through the strata, we will still remain within. It is necessary to disengage from the world of strata, from the actual 
past, passing into the virtual future, even if it is the nearest one. After all, if there are two points of view, namely, strata and Body without Organs, then there is also an opportunity to accept them, i.e. to shift the assemblage point.

It is necessary to be accelerated up to the speed of the world.

Deleuze draws a parallel between Body without Organs and transition to the nagual state, as described by Carlos Castaneda. With the words of Don Juan, Castaneda introduces the distinction between the tonal and the nagual. "The tonal is everything we are," he proceeded. "Name it! Anything we have a word for is the tonal"» (Castaneda, 2007, p. 507) "The tonal is everything we know," he repeated slowly. "And that includes not only us, as persons, but everything in our world. It can be said that the tonal is everything that meets the eye" (p. 508). He equates the tonal with an island where there is everything we know, everything for which we have a word: God, personality, things, words themselves, i.e. our entire world with its orders and chaoses.

But this is only an island. What is outside of it is called the nagual. This is something unknown, this is the hyperchaos, this is Body without Organs. Hypersensitivity. We are always there, but it is not always that we notice this. "This means only one thing: in order to navigate the cyberreality living with us, a person needs to switch over to a different mode of perception, to discover the speed of light in himself or herself" (Volohova, 2019). So this is all about us and our own state. "In the matter itself, there is an exit to a completely different place, where there is neither space nor time, but where the truly global meaning of the universe is revealed at the oultermost limits of the possible, like a revelation" (2019).

Possibility is, but impossible is not.

The nagual, $\mathrm{BwO}$, is what opens beyond the boundaries of the tonal, the strata, i.e. the space of the possible, the potential. The possible is often represented as an extrapolation of what has already happened into the future (the known possible). This possibility is criticized by Bergson and Deleuze for it turns the reality into a consequence of the possible, which in turn is a replication of what has already happened. It makes you see the future as one of the possible repetitions of the past. However, 
the real possibility is the unknown. Potentially, what has happened and what hasn't happened are mixed. After all, the possibility is not totalizable, meaning that everything is possible. The impossible is only a theoretical structure, while the real possible is the unthinkable. Body without Organs is a practice limited only to the potential, only by itself. We either restrict ourselves to the tonal, thus reducing our world to the known, seen and named, or reveal ourselves as Body without Organs, expanding up to the unthinkable limits of the potential.

To be controllable or spontaneous, entangled or boundless, is a matter of the angle of view, the assemblage point.

Given the possibility of passing into the nagual so as to become Body without Organs, i.e. appearing somewhere there is - can be - no control, as the control resides only where there are strata, there is no need in seeking some greater freedom. We are always free ontologically, whether at home or outdoors, on our own or someone else's territory, at liberty or in prison. Wherever we are able to become $\mathrm{BwO}$, we as able to find ourselves on the other side of the stratification.

That said, in ages, we have formed the habit of being slaves.

Let us say that we have made the first step, the first intention to infinity. We perceive the life as a power hidden behind its manifestations. We realize that this power has no boundaries in the common sense of the term. We recognize that the body represents a nameless matter capable of being more than a given set of functions originated by the organization. We understand that every instinct presupposes some variability and improvisation in its performance (Massumi, 2019). However, for now, this is still nothing but a mental experience. An imaginary experiment. And once we take only one step, we will once again find ourselves in the world of strata, measurabilities and certainties. The power of habits, reflexes and other automatic behavior will bring us back to the limited reality. Therefore, in addition to the inherent ontological freedom of the life as an inactive force of the potential, there is also the fight of bodies for liberation. However, this fight is not a fight for freedom, as there is no sense in fighting for what is given by default.

Liberation is not the doorway to freedom, but rather the movement of freedom itself, sweeping away any obstacles. 
Anyway, we have an organism, and its complete destratification will lead to death. How to liberate the body from the organism? Antonin Artaud who was the first to discover Body without Organs has left a fairly large number of remarks in this respect. Comparing the theater to the plague, he notes "that the only two organs really affected and injured by the plague, the brain and the lungs, are both directly dependent upon the consciousness and the will" (Artaud, 1958, p. 21). Our body has two organs that obey the will, the organs for which we can set a rhythm. Having passed into the nagual and recognized ourselves as Body without Organs, we begin to move towards becoming the same, thus determining the trend. The thought, originally spontaneous, will transmit its rhythm to our breath. "What voluntary breathing provokes is a spontaneous reappearance of life" (p, 136).

The breath will transmit its rhythm to the heart, and thus the body will become a conductor of passion. The passion will create a tension that will destratify partially the body, making it to rebuild following the trend determined. It is often said that the body is a receptacle of automatism, a kind of something unconscious and reflexive. Rather a kind of a ruler than a slave. However, this is nothing but the granted reality that we can change. Why should we reduce our mental activity to just a linear internal monologue? Why should we do nothing but imagine, digging deeper and deeper into the depths of abstraction? The thought produces a material effect, and the passion is of material nature. Think with affects, think with the body. "To know that a passion is material, that it is subject to the plastic fluctuations of material, makes accessible an empire of passions that extends our sovereignty" (p. 135). Recode the instincts, transmute the functions - not to destroy the body, but to create a new body.

The search for a new identity is not something that is done only once.

In recent years, many new identities have been developed, namely, cyborgs, cyber shamans, space witches, new pagans etc., just to name a few. However, they all are governed by the same wish - to identify themselves as someone [certain]. Why not "be a little alcoholic, a little crazy, a little suicidal, a little of a guerilla" (Deleuze, 1990, 157), a little of a magician and something of a scientist?? Why do we not present an ultimatum to the social 
roles and declare ourselves "no one"? "No one can do it!" - "and I am no one". No one means anybody. Nobody = Something. Why not be something plastic and imageless, like the monster in the well-known John Carpenter's movie, i.e. [some]thing able to take any shape, any form, depending on the circumstances? Nobody and Something are two readings of the same impossible non-identification: the sadistic interpretation implying comprehensive negation of any shapes (Nobody) and the masochistic mythology of sacred super-completeness (Something). It is not enough to draw the line of flight only once, since very soon you may find yourself again to be a slave to some new organization. The escape lines must be drawn anew each time. Time and time again we have to make our journey to the vast desert of the nagual so as to come back born anew.

This is the way: Body without Organs - rhythm - breath heart -organization - body - immediate surrounding - socius.

This is the only way for a revolution, rather than another slave revolt, to become possible. The "oppressed" have always done nothing but swapped one order for another. They have simply bargained one oppression for another. Perhaps, they always see nothing but repression because this is what they want. Stop being neurotic, stop feeling humiliated and insulted. Only one kind of revolution is possible, the multiple and ever-varying one opening the doorway to liberation, the revolution of the self. The wish itself is revolutionary. Originating with the freedom, it propagates the same in all directions. It changes the reality by its very presence.

\section{5}

One may get an impression that there is nothing more distinct from each other than Body without Organs and media. Something silent, complete, imageless and nameless against the never-ceasing circulation of signs and images. While $\mathrm{BwO}$ is the ultimate future in the present, the media reality, i.e. the communicative reality, it represents the eternal coming of letters from the past. That's why so many authors are ready to accuse the media in all sins - control, zombification, censorship, brainwashing and imposing consumer instincts. Of course, we might as well follow this way, but what will it result in? What is the result of the reproach other than fruitless negative effects? 
What can the exclusive disjunction produce other than some logical abstractions?

Every separation, by its very presence, connects two separated poles. The disjunctive synthesis provides the way to approach the problem of co-functioning of $\mathrm{BwO}$ and media so as to see the elusive effects instead of being abandoned to criticism demonizing either of the terms.

To be Body without Organs - Land, Money, State, Community, People etc. - means to feel involved in something more than one's "own" organism or personality. Contactless connection across time and space - this is the belonging granted by Body without Organs, the sense of unity with those whom we have never met, who may be just coming.

Through rituals and sacrifice, societies have since ancient times cultivated this sense of belonging as a sacred unity in indistinguishability existing in parallel with the secular mode where social differences are in effect. Under the name of Conciliarity, this phenomenon was appropriated by the theology as the unity of the religious. As a result, it has had for long a distinctly religious connotation, resulting in its shrinking within the religious discourse and the art. It is through the art that the phenomenon of belonging managed to go beyond the boundaries of the theology, whereupon - in the age of technical reproducibility, when the art escaped from the stuffy museums, propagating itself across the entire social space - it could find the fullness of expression as the potentiality.

A media theorist whose look is stuck to the communication networks and ever-propagating images and codes and who sees the media as a prosthetic device or machinery, often overlooks the sacred aspect of belonging conveyed along with messages and/or generated by the same.

A movie, a computer game, a photo, a book, the music - all of them contain the whole world in a contracted form, should it be some fantastic, fantasy or "documentary-historical" content. For example, the "soviet classics" creates the sense of belonging to the past that may never have been, and in this respect it differs little from the worlds of David Lynch or Andrzej Sapkowski, the Simpsons or Kafka. Something has happened in the additional virtual dimension, and the medium is a gateway allowing us not only to look, but also to join. 
But this is not about the medium, as the medium itself is just one of the machines registered along with the entire lore on Body without Organs. Here, if we do not want to overlook the main effects generated by "the life of the Death in the capitalist entertainment", we should not misunderstand Body without Organs to be the characters, things or events that take place in one or another world. All this takes place, and this is how it is registered on $\mathrm{BwO}$. The same applies to the historical chronology - it is present on $\mathrm{BwO}$, however, just as an intensive entity with the potential to be actualized. Not only "the content" itself, but also the accompanying merch - Doctor Who's sonic screwdrivers, Witcher medallions, Funko Pop figurines represent the gates through which we are infected with belonging to Body without Organs in one or another additional dimension. "The mass culture's artifacts like "Star wars" provide the starting point for our fantasy. A good image and a good design is a kind of a mental toy that offers a wide variety of games: from the theorycraft, disputes over the lore and fanfiction to buying tangible souvenirs" (Kardash, 2020). All sorts of actualization are at the same time the gateway to the world and also something that, while residing on $\mathrm{BwO}$, allows us to find ourselves there too, through the contactless connection Yoel Regev speaks about. We don't have to carry a merch or hold it in hands; sometimes it's enough to see it. We don't have to review a movie or reread a book; sometimes it's enough to recall them to find ourselves on the same Body without Organs along with their world.

And it is the presence on Body without Organs of any universe that produces special sensations. For example, when some favorite TV serial comes to its end, there is a sense of belonging, often in the form of light sadness. With no encounter with the actual images, we still remain in the same space with them, and since BwO is the very minimum of intensive existence of this space, it turns to be not enough for us. And it is the impulse caused by this, the impulse to increase the intensity of experiencing our belonging to $\mathrm{BwO}$, that appeals to look for new actualizations. Using this emotional experience, they sold us various "inspired" products - comics, T-shirts, movies inspired by games and books inspired by movies. But this impulse can also result in various creative activities - fanfiction, cosplay, 
role-playing case scenarios etc. All of them stem from the wish to stay on a specific Body without Organs. Either in playing a character, or writing one's own story, or in shooting a fan video, there is a power of vitality, as in the tiger game of a child as described by Brian Massumi: «The child is far from imitating the visible corporeality of a tiger, but overcomes the tiger's style of action by transposing it onto his (her) own corporeality. The child catches the tiger's dynamism as a form of the life and sees the affect of the tiger's vitality: the potentially creative powers of the life» (Massumi, 2019, p. 105). From this perspective, the media can be seen not as a "machine of influence" reproducing and transferring various codes and images that infect us, but as a mad maze allowing us to travel around different worlds; involving us in virtual spaces of belonging and joint playing on common Body without Organs together with those who are far from us; the spaces where we can revive ourselves with the vital force and find the tendencies towards transcendence of the social reality and the everyday routine.

Of particular interest is the mechanics of registration, through which two different BwOs can be combined - touchless - in a way unique to them. A good example is the crossover encounter of two or more fictional universes within the same story. Thus, in the final episode of the first season of animated series "Disenchantment", characters from animated series "Futurama" appear just for a few moments; however, even such a little is enough to unite both universes. Bodies without Organs merge with each other; however, given the absence of any outlined borders, they do this in a way other than mixing "physical" bodies. The crossovers trigger the cross-process that consists in parallel registering the machines of one $\mathrm{BwO}$ on the other one until they become indistinguishable. It is not the contactless connection, but rather the contactless fusion, the fusion without fusion that takes place in a special, intensive, Spatum.

Next to the registration, there is another mechanism, the connective synthesis that links different machines to each other. The media world - the world of messages and simulacra reveals new links that are not yet possible in the "physical" world, starting from the myths about merging everything with everything, and ending with movies that represent particular 
variations. In "Roboshark", "Zombie Shark", "Sharknado", "Sharkenstein", "Sharktopus", the links and mergers that existed as virtual ones are actualized in images and spread over the communication networks, gaining more and more manifestation and reality. However, emergence of new actual links and imparting them the features of reality, so that Walt Disney appears less real than the talking mouse in red shorts, is only a part of media's merits. The other part are the virtual links. For example, Xi Jinping appears to be associated with Winnie the Pooh, and Alexander Dugin - with Sergei Pakhomov (of course, without an actual contact). The media are a machine for producing and distributing the impossible possible on a planetary scale. «God is in the TV».

Another mechanism is the disjunctive synthesis that establishes divergences between trajectories and points of view as possible worlds. These disjunctions are established outside «the preceding norm or the standard that would guide it» (Shaviro, 2018, p. 143). This can be best demonstrated in the genre of "theater of one actor" - should it be "Attention: Modern 2", "A Bit of Fry \& Laurie" or Anton Lapenko's performances where each new character, as a point of view of the world, arises and exists owing to its distinctions from the other characters. Thus, "Pokemons" or superheroes represent an open system where you can add new variations over and over again, provided that the only disjunction rule is met: they must be different from the other characters. At the same time, these differences will combine them into a system. However, this apply not only to the characters; the trajectories may ramify as a series of choices, as is the case in "Mr. Nobody". The modern media are based on the same principle: a new product should be different from the others, especially when it comes to a remake. The genealogy appears to be derived from this logic of simulacra: the auteur cinema does not arise as a result of the competence; on the contrary, the director's competence is the result of his (her) success, and the "author's style" is refined and maintained in this space of difference. The variability increases with every step forward, and each series generates other series, expanding the space of possible worlds to be actualized.

This is the media in terms of Body without Organs and its mechanisms. This viewpoint both goes against and complements 
the one from which the media appear as a network over which codes, commands and appealing images are propagated and monetized. On the one hand, we have infection and standardization. On the other - variations and mutations. However, this is not limited to these two viewpoints, because as long as we can see this complementarity, co-functioning, there is another viewpoint, the third one, from where the former two are both visible.

There is also the fourth viewpoint that deserves special notice, the one developed by Yoel Regev, from where the resonance is revealed as a special mechanism. This is important, because it allows us to see Body without Organs as a body of resonance. The resonance is self-organizing: in such a way, the applauding audience is synchronized, so that the process becomes self-sustaining and each continues as far as the others continue. The three Bodies without Organs, as identified by Deleuze and Guattari in their Anti-Oedipus, namely, the body of the Earth, the body of the Despot, and the body of the Money, differ primarily in what (who) sets the rhythm, i.e. acts as the rhythm-setter, synchronizing all other processes, whether it pertains to planetary cycles, despot's disposition and will, or games of rates and prices ${ }^{15}$. It is from this viewpoint that you can see how BwO arises as a contactless connection between individual machines. In terms of the strata, BwO arises at the last step as the resonance between diverging/connected trajectories, while in terms of $\mathrm{BwO}$, everything happens just the other way round: the machines are registered while being in resonance, enter into connections and diverge relative to each other, already residing on $\mathrm{BwO}$ and thus being interconnected. It is from this viewpoint, as held by Regev, that both the BwO integrity that overrides any coincidence and the randomness of an encounter between individual machines appear to be the consequences of the resonance as a coincidence.

Another Regev's merit is that, highlighting the concept of "resonance" and giving it weight, he gives us a new optics through which we can view the media as Resonance Machine. The resonance appears to be the primary not in its origin, but in

\footnotetext{
${ }^{15}$ A good starting point for learning the subject of synchronization - 21. Strogatz, H.S. (2003) SYNC. How order emerges from chaos in the universe, nature, and daily life. NY: Penguin Group.
} 
its speed of action. Yes, the media are a network, a rhizome. However, it arises as a result of organization and solidification. Yes, the media spread the viral content; however, didn't this happen before the media age, even if at a slower rate? For example, through the word of mouth or social relations. The new thing that comes with the media is the possibility of large-scale public response, global synchronization. The concept of viral infection is undoubtedly true, however, it overlooks the fact that the infection is preceded by the resonance. It looks as if the community developed as a result of propagation of similar viral images, words, or ideas. However, the possibility of a coincidence should not be excluded, i.e. there is always a possibility that different individuals appear "accidentally" to be in accord, while not being in touch before. It is the media development that opened up the era of large-scale public response.

The mechanism of resonance is also applicable to an individual medium. Although it is true that any medium can be understood as "a layer of conventions that are never resolved completely within the physicality of the basis", and that it is of "self-distinct" nature (Krauss, 2017, p. 80), any medium, even if it includes the circumstances of its perception, gains the integrity through resonance, resulting that it appears as a kind of unity, interlinking the layers and the contexts, while not removing any contradictions between them.

However, coincidence of Regev's viewpoint with the media imposes some restrictions, apart from the obvious advantages. Indeed, his viewpoint is in accordance with the media's one. The virology and resonance are two mechanisms clearly visible from the latter, while the network and self-organizing systems appear to be behind the back, thus being swept aside as "boring and tedious". Here the "boredom" and "attractiveness" represent the main value-based opposition and selection criterion (based on which he criticizes both fronts of the accelerationism). However, the main thing is a dream about the True Attraction. The goal is "to ensure the maximum preference for the sensorimotor circuits leading to an increase in the "joy factor" (Regev, 2018, p. 153) using the "opti-mixing" principles that provide the "guidelines for choosing non-coinciding timespans in each specific situation" (p. 155). In the final analysis, this goal represents the challenge facing the neural networks like those 
used in Netflix for selecting and recommending the movies to be seen, so that each user gets nothing but what will lead to an increase in the "joy factor". The "True Attraction" turns out to be the "Infinite Jest", an ideal entertainment that ultimately brings nothing but degradation: "Perhaps the facts are true, after the first watching: that then there seems to be no choice. But to decide to be this pleasurably entertained in the first place. This is still a choice, no? Sacred to the viewing self, and free? No? Yes?" (Wallace, 2019, p. 507). What Regev suggests is creation of a new heroin using philosophical methods. And even if this is a risk that we can take, we should first pay attention to something else, something that distinguished William Burroughs from spineless drug takers, allowing him to develop the Cut-Up method and the Word-Virus theory, namely, the practice of self.

The phenomenology and psychoanalysis formed the scientific basis for determining the viewpoint. Following Nietzsche, Deleuze makes navigating between different points of view, as well as changing perspectives, one of his key tools. This is where the majority of modern philosophical trends lose away, appearing to represent only particular viewpoints and firmly established perspectives as it pertains to various objects, correlationism, assemblages, horror etc. They do not need to be rejected, they do not need to be criticized as well (after all, is not the criticism just an unwillingness to accept some other point of view, or an attempt to disengage instead of experimenting?). Development of a technology for navigating across different points of view, and therefore across potential worlds - here is a challenge worthy of the modern philosophy. The science of navigating across the worlds simply by shifting the assemblage point - isn't it the science that can open an access to "a maximum of calculated sobriety in relation to the disparate elements and the parameters" ${ }^{\prime 16}$ (Deleuze, 1987, p. 344)? Moreover, we have long had a perfect tool that allows us to perceive all existing points of view at once - Body without Organs. As long as

\footnotetext{
${ }^{16}$ Introducing the concept of "zoom movement", Yoel Regev takes the first steps in this field. However, this is still about the approach movement ("zoom") within a single point of view. It is necessary to introduce a certain "side-" or "slide-movement", i.e. taking another point of view, while preserving the scale. Perhaps, the philosophy of video games that have already been tearing the palm from the cinema will provide the required tooling. The ability to change a character right during the match as in "Overwatch" is one of the mechanisms of a good attraction that has already inspired release of series like "Mosaic" by Steven Soderbergh.
} 
the disjunctive syntheses that establish the divergence of trajectories work on BwO, it represents a space of viewpoint variations comprising them all. To become Body without Organs means to choose all possible worlds at once, to be suspended between them, so that you can choose any one at your discretion, depending on the circumstances. Thus, God is Body without Organs, not least because He takes all possible points of view at once. The library of viewpoints is constantly updated, owing to the philosophy, literature, movies, video games etc. We only have to learn how to navigate it. Then the media can be considered as a dispatch service to distribute trial samples of possible perspectives.

In conclusion, we only have to outline the boundaries of both the media and Regev's viewpoint that coincides with the media's one. Saying that "the Earth will have to move" (Regev, 2018 , p. 155) ${ }^{17}$, he reveals his system of coordinates. After all, it is only from the ground that the Earth seems immovable. The media are still confined within the globe, while it is long past time to "capture the mute and unthinkable forces of the Space". Yes, the media attention to the ecology should bear fruit, however, this is just a problem to be solved, and this should be done as soon as possible. It's time to see the Earth not only as our only home, but also as "one galaxy among others". "The modern figure is not the child or the lunatic, still less the artist, but the cosmic artisan" (Deleuze, 1987, p. 345). It's time to proceed from assemblages to Body without Organs, from the galaxy of media to the galactic media. We have only a few minutes left. And we open into Space.

References

Artaud, A. (1958). The Theatre and Its Double. NY: Grove Press.

Budanov, V.G. (2017). Methodology of synergetic in postnonclassic science and education. Moscow: LELAND (in Russian).

Castaneda, C. (2007). The Teachings of Don Juan. A Separate Reality. Journey to Ixtlan. Tales of Power. Moscow: «Sofia» (in Russian).

\footnotetext{
${ }^{17}$ This is also indicated by all the other rhetoric related to "the ground under your feet", "redrawing of the land", with all its trees and winds.
} 
DeLanda, M. (2006). A New Philosophy of Society: Assemblage Theory And Social Complexity. London \& New York: Continuum.

Deleuze, G. (1983). Anti-Oedipus: Capitalism and Schizophrenia. London \& New York: Continuum.

Deleuze, G. (1987). A Thousand Plateaus: Capitalism and Schizophrenia. Minneapolis: University of Minnesota Press.

Deleuze, G. (1988). Bergsonism. NY: Zone Books.

Deleuze, G. (1991) Masochism: An Interpretation of Coldness and Cruelty. NY: Zone Books.

Deleuze, G. (2015). Lectures on Leibniz. 1980, 1986/87. Moscow: Ad Marginem Press (in Russian).

Deleuze, G. (2016). Lectures on Spinoza. Moscow: Ad Marginem Press (in Russian).

Juran, A. (2018, February 15). Death drive or model of becoming in psychoanalysis. Sygma. Retrieved from https://syg.ma/@lacanalia/aitien-iuran-vliechieniie-k-smierti-ili-mo diel-stanovlieniia-v-psikhoanalizie (in Russian).

Kardash, A. (2020, February 14). Dartmolisation. Sygma. Retrieved from https://syg.ma/@insolarance-cult/dartmolizatsiia (in Russian).

Krauss, R. (2017). A Voyage on the North Sea: Art in the Age of the Post-Medium Condition. Moscow: Ad Marginem Press (in Russian).

Land, C. (2005). Apomorphine Silence: Cutting-up Burroughs' Theory of Language and Control._Ephemera, 5(3), 450-471. Retrieved from http://www.ephemerajournal.org/sites/default/files/5-3land.pdf

Massumi, B. (2019). What Animals Teach Us about Politics. Perm: Hyle Press (in Russian).

Merzlyakov, S.S. (2019). What is philosophy? Philosophy of Economy, (4), 256-265. (in Russian).

Morin, E. (2007). On complexity. Cresskill, NJ: Hampton Press.

Regev, Y. (2016). Impossible and coincidence. On the revolutionary situation in philosophy. Perm: Hyle Press (in Russian).

Regev, Y. (2018). DISS-NEY-LAND. Logos, (2), 139-158. Doi: 10.22394/0869-5377-2018-2-139-156 (in Russian).

Sade, M. D. (2011). Philosophy in the Bedroom. Moscow: AST: Astrel: Poligrafizdat (in Russian).

Shaviro S. (2018). Without Criteria: Kant, Whitehead, Deleuze, and Aesthetics. Perm: Hyle Press (in Russian). 
Thanem, T. (2007). "The body without organs: Nonorganizational desire in organizational life', Culture and Organization, 10(3), 203-217. Doi: https://doi.org/10.1080/14759550412331297147

Volohova, A. (2019, April 8). From «society of control» to selfcontrol. Sygma. Retrieved from

https://syg.ma/@anastasiia-volokhova/anastasiia-volokhova-ot-obs hchiestva-kontrolia-do-samokontrolia (in Russian).

Wallace, D.F. (2019). Infinite Jest. Moscow: AST. (in Russian).

Woodard, B. (2016). Slime Dynamics. Perm: Hyle Press (in Russian).

Список литературы

Artaud, A. (1958). The Theatre and Its Double. NY: Grove Press.

DeLanda, M. (2006). A New Philosophy of Society: Assemblage Theory And Social Complexity. London \& New York: Continuum.

Deleuze, G. (1983). Anti-Oedipus: Capitalism and Schizophrenia. London \& New York: Continuum.

Deleuze, G. (1987). A Thousand Plateaus: Capitalism and Schizophrenia. Minneapolis: University of Minnesota Press.

Deleuze, G. (1988). Bergsonism. NY: Zone Books.

Deleuze, G. (1991) Masochism: An Interpretation of Coldness and Cruelty. NY: Zone Books.

Land, C. (2005). Apomorphine Silence: Cutting-up Burroughs' Theory of Language and Control._Ephemera, 5(3), 450-471. Retrieved from http://www.ephemerajournal.org/sites/default/files/5-3land.pdf

Morin, E. (2007). On complexity. Cresskill, NJ: Hampton Press.

Thanem, T. (2007). 'The body without organs: Nonorganizational desire in organizational life', Culture and Organization, 10(3), 203-217. Doi: https://doi.org/10.1080/14759550412331297147

Буданов, В. Г. (2017). Методология синергетики в постнеклассической науке и в образовании. Москва: ЛЕЛАНД

Волохова, А. (2019, April 8). От «общества контроля» до самоконтроля. Sygma. Retrieved from https://syg.ma/@anastasiia-volokhova/anastasiia-volokhova-ot-obs hchiestva-kontrolia-do-samokontrolia (in Russian).

Вудард, В. (2016). Диналика слизи. Зарождение, мутащия и ползучесть жизни. Пермь: Hyle Press 
Делёз, Г. (2015). Лекиии о лейбнище. 1980, 1986/87. Москва: Ад Маргинем.

Делёз, Г. (2016). Лекиии о Спинозе. Москва: Ад Маргинем.

Кардаш, А. (2020, February 14). Дартмолизация. Sygma. Retrieved from https://syg.ma/@insolarance-cult/dartmolizatsiia

Кастанеда, К. (2007). Учение дона Хуана: Путь знания индейцев - яки. Москва: «София».

Краусс, Р. (2017). Путешествие по Северному морю: искусство в эпоху постледиальности. Москва: Ад Маргинем.

Массуми, Б. (2019). Чему животные учат нас в политике?. Пермь: Hyle Press

Мерзляков, С.С. (2019). Что такое философия? Философия хозяйства, (4), 256-265.

Регев, Й. (2016). Невозможное совпадение: о революционной ситуации в философии. Пермь: Hyle Press.

Регев, Й. (2018). Дисс-на-Land. Логос, (2), 139-158. Doi: 10.22394/0869-5377-2018-2-139-156

Сад, М. Д. (2011). Философия в будуаре или Безнравственные учителя. Москва: АСТ, Астрель: Полиграфиздат.

Уоллес, Д.Ф. (2019). Бесконечная шутка. Москва: АСТ.

Шаиро, С. (2018). Вне критериев: Кант, Уайтхед, Делез и эстетика. Пермь: Hyle Press.

Юран, А. (2018, February 15). Влечение смерти или модель становления в психоанализе. Sygma. Retrieved from https://syg.ma/@lacanalia/aitien-iuran-vliechieniie-k-smierti-ili-mo diel-stanovlieniia-v-psikhoanalizie 